\title{
Homosexuality and venereal disease in the United Kingdom
}

\author{
A second study
}

\author{
BRITISH CO-OPERATIVE CLINICAL GROUP*
}

SUMMARY The proportion of homosexually acquired cases of primary and secondary syphilis in patients attending venereal disease clinics in the United Kingdom has risen from $42 \cdot 4 \%$ to $54 \%$ over a six-year period. Similarly, over the same period, the proportion of homosexually acquired cases of gonorrhoea has risen from $9 \cdot 8 \%$ to $10.9 \%$. The increase in incidence of homosexually acquired infections in both diseases occurred in all areas but particularly in London. Thus the very considerable epidemiological importance of male homosexuals as a high-risk group should receive more, not less, emphasis.

\section{Introduction}

In 1971 a study was carried out by the British Cooperative Clinical Group of the proportion of cases of primary and secondary syphilis and of gonorrhoea reported in male patients in the venereal disease clinics of the United Kingdom believed to have been homosexually acquired. ${ }^{1}$ The present paper reports a similar study undertaken in 1977 and compares the results of the two surveys.

As in the previous study, the venereologists in charge of the clinics were asked to provide information on the number of anorectal and penile infections believed to have been homosexually or heterosexually acquired; but, in the recent study, infections which may have been acquired orally were also recorded. The figures are again presented separately for England, Wales, and Scotland, and on this occasion include data from Northern Ireland. As before, the figures for England are broken down according to the population size of the towns or cities in which the participating clinics are situated.

\section{Patients and methods}

The geographical distribution of the participating clinics is shown in Table $I$, together with the population of the towns and cities in which the clinics are situated.

*A list of participatory clinics is given in the appendix

Address for reprints: Dr R R Willcox, St Mary's Hospital, London W2

Received for publication 3 January 1979
The distribution of clinics was similar in the two studies, although the 1977 survey is less complete for England as three major clinics which participated in the earlier study failed to produce data for the 1977 one-in two instances an unjustified reliance had been placed on computers.

\section{CLINIC ATTENDANCES}

In 1977,1364 cases of primary and secondary syphilis and 33826 cases of gonorrhoea were recorded (Table II). According to the 1977 study the number of cases of gonorrhoea in England was notably lower than in 1971 , owing mainly to the non-participation of three

TABLE I Distribution of clinics in relation to size of towns and cities

\begin{tabular}{|c|c|c|c|c|}
\hline \multirow{2}{*}{$\begin{array}{l}\text { Area and } \\
\text { population } \\
\text { size }\end{array}$} & \multicolumn{2}{|l|}{1971} & \multicolumn{2}{|l|}{1977} \\
\hline & Clinics & $\begin{array}{l}\text { Towns or } \\
\text { cities }\end{array}$ & Clinics & $\begin{array}{l}\text { Towns or } \\
\text { cities }\end{array}$ \\
\hline \multicolumn{5}{|l|}{ England } \\
\hline 50000 or less & 42 & 42 & 40 & 40 \\
\hline $50001-100000$ & 48 & 48 & 57 & 57 \\
\hline $100001-500000$ & 35 & 35 & 33 & 33 \\
\hline 500001 or more & 7 & 5 & 6 & 4 \\
\hline London & 20 & 1 & 17 & 1 \\
\hline Total & 152 & 131 & 153 & 135 \\
\hline Scotland & 13 & 11 & 15 & 15 \\
\hline Wales & 11 & 11 & 7 & 7 \\
\hline N. Ireland & ND & ND & 3 & 3 \\
\hline Total & 176 & 153 & 178 & 160 \\
\hline
\end{tabular}

$\mathrm{ND}=$ no data 
TABLE II Number and source of infection of cases of primary and secondary syphilis and gonorrhoea for 1971 and 1977

\begin{tabular}{|c|c|c|c|c|c|c|}
\hline \multirow[b]{2}{*}{ Area } & \multicolumn{2}{|c|}{ No of cases } & \multicolumn{2}{|l|}{ Contact (1977) } & \multicolumn{2}{|c|}{$\%$ homosexually acquired } \\
\hline & 1971 & 1977 & Heterosexual & Homosexual & 1971 & 1977 \\
\hline $\begin{array}{l}\text { Primary and } \\
\text { secondary s } \\
\text { England } \\
\text { Scotland } \\
\text { Wales } \\
\text { N. Ireland } \\
\text { Total }\end{array}$ & $\begin{array}{r}830 \\
52 \\
42 \\
\text { ND } \\
924\end{array}$ & $\begin{array}{c}1193^{*} \\
105 \\
57 \\
9^{*} \\
1364\end{array}$ & $\begin{array}{r}500 \\
71 \\
49 \\
7 \\
727\end{array}$ & $\begin{array}{r}692 \\
34 \\
8 \\
2 \\
736\end{array}$ & $\begin{array}{r}45 \cdot 9 \\
13 \cdot 5 \\
9 \cdot 5 \\
\text { ND } \\
42 \cdot 4\end{array}$ & $\begin{array}{l}58 \cdot 1 \\
32 \cdot 4 \\
14 \cdot 0 \\
22 \cdot 2 \\
54 \cdot 0\end{array}$ \\
\hline $\begin{array}{l}\text { Gonorrhoea } \\
\text { England } \\
\text { Scotland } \\
\text { Wales } \\
\text { N. Ireland } \\
\text { Total }\end{array}$ & $\begin{array}{r}32328 \\
2822 \\
1092 \\
\text { ND } \\
36242\end{array}$ & $\begin{array}{r}29501 \\
3478 \\
591 \\
256 \\
33826\end{array}$ & $\begin{array}{r}26088 \\
3262 \\
548 \\
211 \\
30139 \\
\end{array}$ & $\begin{array}{r}3413 \\
216 \\
43 \\
15 \\
3687\end{array}$ & $\begin{array}{r}10 \cdot 5 \\
4 \cdot 1 \\
4 \cdot 0 \\
\mathrm{ND} \\
9 \cdot 8\end{array}$ & $\begin{array}{r}11 \cdot 6 \\
6 \cdot 2 \\
7 \cdot 3 \\
5 \cdot 9 \\
10 \cdot 9\end{array}$ \\
\hline
\end{tabular}

ND = no data

* One patient who denied sexual contact was excluded from the analysis

large clinics, but this is insufficient to conceal a marked increase in the number of cases of primary and secondary syphilis in 1977.

\section{Results}

PRIMARY AND SECONDARY SYPHILIS

Of the 1363 cases of primary and secondary syphilis included in the 1977 study, $625(45.9 \%)$ were penile infections heterosexually acquired, $355(26 \%)$ were penile infections homosexually acquired, and 366 $(26.9 \%)$ were homosexually acquired anorectal infections. Oral contact was the only source of infection in 15 homosexuals and two heterosexuals (total $1 \cdot 2 \%$ ). In all, $54 \%$ of infections were homosexually acquired and $46 \%$ heterosexually acquired. The proportion was highest $(58 \cdot 1 \%)$ for the clinics in England, less in Scotland $(32.4 \%)$ and Northern Ireland $(22 \cdot 2 \%)$, and lowest in Wales (14\%) (Table II).

All these figures are higher than those in the 1971 study. In England, for example, the percentage of acknowledged homosexually acquired infections increased by $12 \cdot 2 \%$ in the six years, in Wales by $4 \cdot 5 \%$, and in Scotland by $18 \cdot 9 \%$.

Homosexually acquired infections in relation to population

In England the data are very striking. The percentage of homosexually acquired syphilitic infections has risen in all areas, especially at clinics in towns or cities with populations of 100000 or less, although this is less marked in London, where in 1971 the percentage was already very high (Table III).

In London, $372(\mathbf{7 0} \cdot 9 \%)$ of 525 cases of primary and secondary syphilis included in this study were treated at five clinics (at the Middlesex, St George's, St Mary's, West London, and Westminster
Hospitals) situated in the West End of the city. In these five clinics the proportion of homosexually acquired infections was $76.9 \%$ compared with $37.9 \%$ in the other participating London clinics (Table III). These figures are very similar to those of 1971.

TABLE III Number of cases of homosexually acquired syphilis in England according to population of towns and cities (1977)

\begin{tabular}{|c|c|c|c|c|}
\hline \multirow{2}{*}{$\begin{array}{l}\text { Population } \\
\text { of town } \\
\text { or city }\end{array}$} & \multirow[b]{2}{*}{$\begin{array}{l}\text { Total } \\
\text { No of } \\
\text { infections }\end{array}$} & \multirow[b]{2}{*}{$\begin{array}{l}\text { Homo- } \\
\text { sexually } \\
\text { acquired }\end{array}$} & \multicolumn{2}{|c|}{$\begin{array}{l}\text { \% homosexually } \\
\text { acquired }\end{array}$} \\
\hline & & & 1977 & 1971 \\
\hline $\begin{array}{l}50000 \text { or less } \\
50001-100000 \\
100001-500000 \\
500001 \text { or more }\end{array}$ & $\begin{array}{r}69 \\
130 \\
311 \\
157\end{array}$ & $\begin{array}{r}30 \\
61 \\
181 \\
76\end{array}$ & $\begin{array}{l}43 \cdot 5 \\
46 \cdot 9 \\
58 \cdot 2 \\
48 \cdot 4\end{array}$ & $\begin{array}{r}9 \cdot 5 \\
28 \cdot 6 \\
30 \cdot 4 \\
16 \cdot 8\end{array}$ \\
\hline $\begin{array}{l}\text { London } \\
\text { West End } \\
\text { clinics (5) } \\
\text { Other clinics } \\
\text { (12) } \\
\text { Total (17) }\end{array}$ & $\begin{array}{r}153 \\
1192\end{array}$ & $\begin{array}{r}58 \\
692\end{array}$ & $\begin{array}{l}37 \cdot 9 \\
58 \cdot 1\end{array}$ & $\begin{array}{l}37 \cdot 2 \dagger \\
45 \cdot 9\end{array}$ \\
\hline
\end{tabular}

*Five West End and +15 other London clinics

Indeed the $\mathbf{2 8 6}$ homosexually acquired infections recorded in the five West End clinics represented $83 \cdot 1 \%$ of the total of 344 homosexually acquired infections in London. On the other hand, the 86 heterosexually acquired infections recorded in the same five clinics represented only $47 \cdot 5 \%$ of the total number of 181 infections acquired heterosexually (Table III).

\section{Individual clinic experience}

The mean number of heterosexually and homosexually acquired cases of syphilis seen in 1977 at 
each clinic according to the size of towns or cities is shown in Table IV.

In Northern Ireland, Wales, Scotland, and towns and cities of less than 100000 population in England, the mean number of syphilitic infections acquired heterosexually each year exceeded those acquired homosexually, whereas in towns or cities of $100001-500000$ population and in London the reverse was true (Table IV).

The mean number of cases of homosexually acquired primary and secondary syphilis for each clinic in 1977 is compared with that in 1971 in Table IV. A sizable increase in 1977 was apparent in all areas.

The mean number of heterosexually acquired infections per clinic in 1977 is also compared with those in 1971. These figures too have risen in all sectors but-apart from Wales-not as markedly as the homosexually acquired infections.

Active-to-passive ratio of homosexually acquired infections

In the 1971 study, of 392 cases of homosexually acquired primary or secondary syphilis $172(43.9 \%)$ were in active homosexuals and $220(56 \cdot 1 \%)$ were in passive homosexuals-that is, anorectally acquired (an active-to-passive ratio of $\mathbf{0} \cdot \mathbf{7 8 : 1}$ ).

In the 1977 study, of 736 homosexually acquired infections $355(48 \cdot 2 \%)$ were penile infections, 366 $(49 \cdot 7 \%)$ were anorectal infections, and 15 (all in England) (2\%) were acquired orally (active-topassive plus oral ratio of $0.93: 1$ ), although in two other cases $(0 \cdot 3 \%)$ the oral route was involved together with one of the other sites.

Oral infections in heterosexuals

It is highly probable that many patients were not questioned about oral intercourse. Whereas 17 $(2 \cdot 3 \%)$ homosexually acquired infections involved the oral route alone or in combination with another site, only two $(0 \cdot 32 \%)$ of the 627 heterosexually acquired infections involved the oral route alone and two, with other sites (a total of $0.64 \%$ ).

\section{GONORRHOEA}

Of the 33826 cases of post-pubertal gonorrhoea recorded in the 1977 study, $30115(89 \%)$ were penile infections acquired heterosexually, $1904(5 \cdot 6 \%)$ were penile infections homosexually acquired, and 1726 $(5 \cdot 1 \%)$ were homosexually acquired anorectal infections. The oral route was the only source of infection in 57 homosexuals and 24 heterosexuals (total $0 \cdot 2 \%)$. In all, 3687 infections $(10 \cdot 9 \%)$ were homosexually acquired and $30139(89 \cdot 1 \%)$ were heterosexually acquired; the figure for heterosexuals contrasts markedly with the $46 \%$ for primary and secondary syphilis (Table II).

As in the 1971 study, the percentage of cases of gonorrhoea in known homosexuals was much higher in England than in Scotland and Wales (as is also now shown for Northern Ireland) and all available data show an increase in the percentage of homosexually acquired infections compared with the previous study in 1971 (Table II).

\section{Homosexually acquired infections in relation to population}

The relatively high incidence of homosexually acquired gonorrhoea in England was mainly accounted for by the London figures; elsewhere in England the proportion resembled that found in Scotland, Wales, and Northern Ireland (Table V).

As with syphilis, the incidence of gonococcal infections in male homosexuals in London was

TABLE IV Mean number of cases of homosexually and heterosexually acquired primary and secondary syphilis per clinic (1971 and 1977)

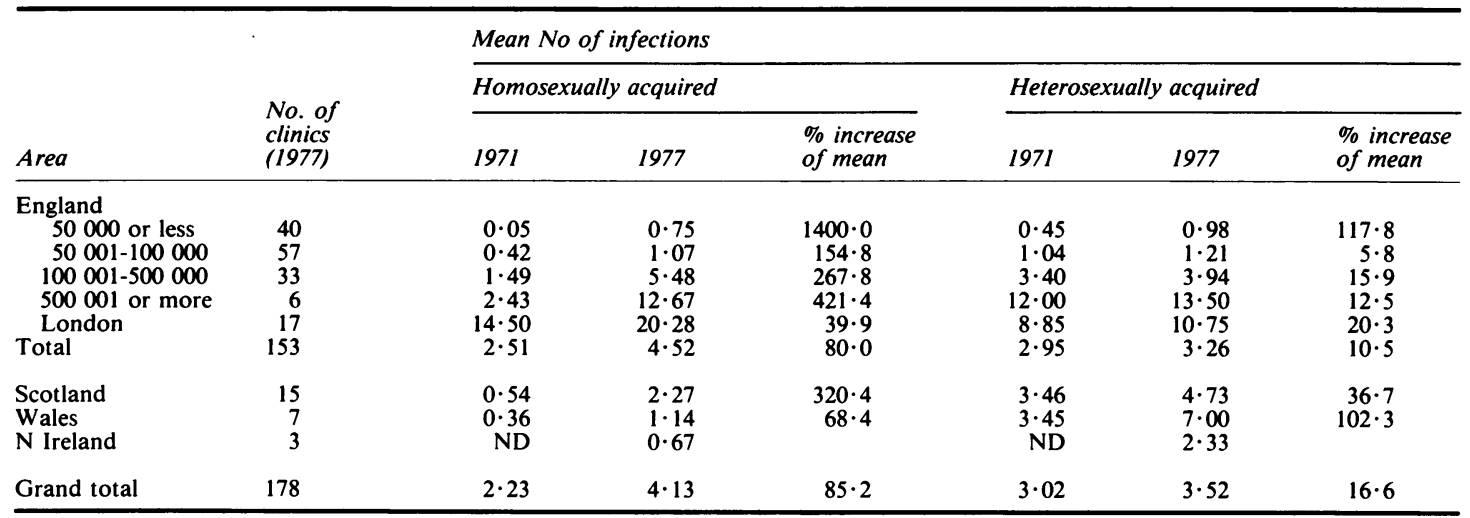

$\mathrm{ND}=$ no data 
concentrated in the five West End clinics already mentioned, where they comprised $28.7 \%$ of infections compared with $8 \cdot 8 \%$ in 12 other participating clinics in the city (Table V).

TABLE V Number of cases of homosexually acquired gonorrhoea in England according to population of towns and cities (1977)

\begin{tabular}{|c|c|c|c|c|}
\hline \multirow{2}{*}{$\begin{array}{l}\text { Population } \\
\text { of town } \\
\text { or city }\end{array}$} & \multirow[b]{2}{*}{$\begin{array}{l}\text { Total } \\
\text { No of } \\
\text { infections }\end{array}$} & \multirow[b]{2}{*}{$\begin{array}{l}\text { Homo- } \\
\text { sexually } \\
\text { acquired }\end{array}$} & \multicolumn{2}{|c|}{$\begin{array}{l}\text { \% homosexually } \\
\text { acquired }\end{array}$} \\
\hline & & & 1977 & 1971 \\
\hline $\begin{array}{c}50000 \text { or less } \\
50001-100000 \\
100001-500000 \\
500001 \text { or more }\end{array}$ & $\begin{array}{l}1481 \\
4378 \\
9178 \\
4168\end{array}$ & $\begin{array}{r}76 \\
197 \\
681 \\
193\end{array}$ & $\begin{array}{l}5 \cdot 1 \\
4 \cdot 5 \\
7 \cdot 4 \\
4 \cdot 6\end{array}$ & $\begin{array}{l}5 \cdot 2 \\
5 \cdot 0 \\
5 \cdot 6 \\
3 \cdot 1\end{array}$ \\
\hline $\begin{array}{l}\text { London } \\
\text { West End } \\
\text { clinics (5) } \\
\text { Other clinics } \\
\text { (12) } \\
\text { Total }\end{array}$ & $\begin{array}{r}3456 \\
29501\end{array}$ & $\begin{array}{r}303 \\
3413\end{array}$ & $\begin{array}{r}28 \cdot 7 \\
8 \cdot 8 \\
11 \cdot 6\end{array}$ & $\begin{array}{l}27 \cdot 6^{*} \\
7 \cdot 7+ \\
10 \cdot 5\end{array}$ \\
\hline
\end{tabular}

*Five West End and +15 other London clinics

Although $66 \cdot 4 \%$ of the total number of cases of gonorrhoea seen at the participating London clinics were treated at the five West End clinics, no less than $86.6 \%$ of the homosexuals with gonorrhoea in London were treated in the same clinics compared with $60.7 \%$ of the heterosexuals with gonorrhoea (4877 out of 8030).

Although the 1971 data were not exactly comparable, the trend was towards an increase in the proportion of known homosexuals with gonorrhoea in all London clinics.
Individual clinic experience

In 1977 the mean number of known heterosexually and homosexually acquired gonococcal infections per clinic in the different areas and according to the size of the town or city in which the clinics are situated in England is shown in Table VI. In England in both groups the mean number increases according to the population size.

The mean number of cases of homosexually acquired gonorrhoea per clinic in 1977 is compared with that in 1971 in Table VI. The increase in the incidence of gonorrhoea is much less than that of primary and secondary syphilis, especially in England.

The mean number of heterosexually acquired gonococcal infections per clinic is shown in Table VI. In England and Wales, unlike the number of homosexually acquired infections, there was an overall decrease in the mean number of infections per clinic although the 1977 figures for England are affected by the lack of data from three major clinics, one in the group of 500000 or more population and two in London.

\section{Active-to-passive ratio of homosexually acquired} infections

In the 1971 study, of the 3549 cases of homosexually acquired gonorrhoea $1945(54 \cdot 8 \%)$ were penile infections and $1604(45 \cdot 2 \%)$ were anorectal infections (active-to-passive ratio of $1 \cdot 2: 1$ ). At that time no data were collected on oral infections.

In the 1977 study, which included 3687 cases of homosexually acquired gonorrhoea, $1904(51 \cdot 6 \%)$ were penile infections, $1726(46 \cdot 8 \%)$ anorectal infections, and $57(1 \cdot 5 \%)$ solely orally acquired infections (active-to-passive plus oral ratio of

TABLE VI Mean number of cases of homosexually and heterosexually acquired gonorrhoea per clinic (1971 and 1977)




1.07:1). In addition, there were 38 other cases of anorectal or penile infections $(1 \%)$ in which oral contact had also occurred. The validity of this data is limited as it is by no means routine practice to take oral specimens for culture from either suspected contacts or those with known gonorrhoea, and thus the proportion of cases in which oral investigations were carried out is not known.

\section{Oral infections in heterosexuals}

Of the 30139 heterosexually acquired cases of gonorrhoea, $30115(99 \cdot 99 \%)$ were penile infections and only 24 were oral, although there were 75 other cases in which oral as well as urethral contact took place. The total number of oral infections was thus $99(0.3 \%)$, but no information is available on the number of patients with urethral infections or of contacts of gonorrhoea without urethral infections who also had oral specimens taken for culture.

\section{GONORRHOEA-TO-SYPHILIS RATIO}

The gonorrhoea-to-syphilis ratios for heterosexually acquired infections are shown in Table VII; the overall ratio was $48 \cdot 1: 1$. The gonorrhoea-to-syphilis ratio of only 5:1 for homosexually acquired infections was nearly one-tenth that of heterosexually acquired infections (Table VII).

TABLE VII Ratio of cases of gonorrhoea to syphilis

\begin{tabular}{lll}
\hline & \multicolumn{2}{c}{ Ratio of No of infections of gonorrhoea to syphilis* } \\
\cline { 2 - 3 } Area & Heterosexually acquired & Homosexually acquired \\
\hline England & $52 \cdot 2: 1$ & $4 \cdot 9: 1$ \\
Scotland & $45 \cdot 9: 1$ & $6 \cdot 4: 1$ \\
Wales & $11 \cdot 2: 1$ & $5 \cdot 4: 1$ \\
N. Ireland & $34 \cdot 4: 1$ & $7 \cdot 5: 1$ \\
Total & $48 \cdot 1: 1$ & $5 \cdot 0: 1$ \\
\hline
\end{tabular}

*Actual numbers of cases for each infection are given in Table II

\section{Discussion}

The reasons for the difference in the ratio of gonorrhoea to syphilis could be that homosexually acquired gonococcal infections are more successfully concealed, although the active-to-passive ratio of declared cases of $1 \cdot 07: 1$ compared with $0.93: 1$ for primary and secondary syphilis does not support this hypothesis. Nevertheless, as in women, asymptomatic infections in passive homosexual men would be expected to be more common than in active homosexual and heterosexual men. Possibly, syphilis is regarded more seriously and contact-tracing carried out more thoroughly for cases of gonorrhoea in homosexuals than in heterosexuals, but it is difficult to see why this should be so.
Thus, some factor-either physical in homosexual acts or behavioural in terms of the frequency of exposure-may well be responsible. But gonorrhoea is more easily acquired from a single exposure than is syphilis, since the latter more often requires frequent contact with the same person. Does this still apply in a homosexual pattern? Or is gonorrhoea more difficult to acquire from an infected, passive homosexual man than from a heterosexual woman?

Possibly it is not the relative lack of gonorrhoea which is the crux of the matter but the great excess of syphilis. Why is syphilis acquired nearly 10 times more frequently by homosexuals than by heterosexuals? Certainly this difference poses an intriguing epidemiological problem.

Both studies leave unanswered the question of whether there has been a real overall increase in those practising homosexuality or merely an increase in infections admitted to have been homosexually acquired. The ratio of heterosexually acquired gonococcal infections to those of primary and secondary syphilis in the clinics in the recent study was $48 \cdot 1: 1$ whereas that for homosexually acquired infections was only $5 \cdot 1: 1$; this highly significant difference likewise needs to be satisfactorily explained.

\section{Appendix}

LIST OF PARTICIPATING CLINICS

\section{ENGLAND}

\section{Under 50000 Population}

Ashton-under-Lyme, Aylesbury, Barnstaple, Bishops Stortford, Boston, Bridgwater, Bury St Edmunds, Canterbury, Dartford, Dorchester, Douglas (Isle of Man), Falmouth, Folkestone, Grantham, Grays, Great Yarmouth, Hereford, Kettering, King's Lynn, Leamington, Loughborough, Milton Keynes, Minster, Newport (Isle of Wight), Newquay, Penzance, Redhill, St Austell, Salisbury, Scarborough, Skegness, Taunton, Truro, Tunbridge Wells, Weymouth, Whitehaven, Winchester, Windsor, Workington, Yeovil. (Forty clinics in $\mathbf{4 0}$ towns or cities; total population 1240935 .)

\section{001-100 000 Population}

Barnsley, Barrow-in-Furness, Bath, Burnley, Burton-onTrent, Bury, Carlisle, Chelmsford, Cheltenham, Chester, Chesterfield, Colchester, Crewe, Darlington, Dewsbury, Doncaster, Eastbourne, Exeter, Gloucester, Gravesend, Grimsby, Guernsey (Channel Islands), Guildford, Halifax, Harrogate, Hastings, High Wycombe, Jersey (Channel Islands), Keighley, Lancaster, Lincoln, Lowestoft, Maidstone, Mansfield, Margate, North Shields, Nuneaton, Peterborough, Preston, Rochester, Rochdale, Rotherham, Rugby, St Albans, Scunthorpe, Stevenage, Southport, South Shields, Torbay, Wakefield, Warrington, Watford, Weston-super-Mare, Wigan, Woking, Worcester, Worthing. (Fifty-seven clinics in 57 towns or cities; total population 4000882 .) 
$100001-500000$ Population

Birkenhead, Blackburn, Blaçkpool, Bolton, Bradford, Brighton, Bristol, Cambridge, Coventry, Derby, Dudley, Huddersfield, Ipswich, Leicester, Luton, Middlesbrough, Newcastle, Northampton, Norwich, Nottingham, Oldham, Oxford, Plymouth, Portsmouth, Reading, Stockport, Stoke-on-Trent, Southampton, Southend, Sunderland, Walsall, Wolverhampton, York. (Thirty-three clinics in $\mathbf{3 3}$ towns and cities; total population 6576520 .)

Over 500000 Population

Leeds, Liverpool (two clinics), Manchester (two clinics), Sheffield. (Six clinics in four cities; total population 2117 200.)

\section{LONDON}

Central Middlesex Hospital, Croydon Hospital, Dreadnought Hospital (Greenwich), Guy's Hospital, Holloway Prison, Eastern Hospital, Middlesex Hospital, Old Church Hospital (Romford), Royal Free Hospital, Royal Northern Hospital, St Bartholomew's Hospital, St George's Hospital, St Giles Hospital (King's College Hospital), St Helier Hospital (Carshalton), St Mary's Hospital, West London Hospital (Charing Cross), Westminster Hospital. (Seventeen clinics; population 7281080 .)

\section{SCOTLAND}

Aberdeen, Ayr, Dumfries, Dunfermline, Dundee, Edinburgh, Falkirk, Fort William, Greenock, Glasgow, Hamilton, Inverness, Kirkaldy, Perth, Stirling. (Fifteen clinics in 15 towns or cities; total population 2072 905.)

WALES

Aberystwyth, Cardiff, Carmarthen, Haverfordwest, Pontypridd, Port Talbot, Swansea. (Seven clinics in seven towns or cities; total population 567 100.)

NORTHERN IRELAND

Belfast, Coleraine, Londonderry. (Three clinics; total population 456850 .)

\section{References}

1. British Co-operative Group. Homosexuality and venereal diseases in the United Kingdom. Br J Vener Dis 1973; 49; 329-34. 